\title{
Water scarcity footprint of primary aluminium
}

\author{
Kurt Buxmann $^{1}$ • Annette Koehler ${ }^{2}$ • Daniel Thylmann ${ }^{3}$
}

Received: 14 May 2015 / Accepted: 30 October 2015 / Published online: 29 January 2016

(C) The Author(s) 2015. This article is published with open access at Springerlink.com

\begin{abstract}
Purpose The cradle-to-gate water scarcity footprint (WSFP) of primary aluminium has been determined for global aluminium including China (GLO) and global aluminium excluding China (RoW). It consists of the following:

- the direct WSFP, based on the freshwater consumption data collected by the IAI from global bauxite mines, alumina refiners and aluminium smelters and the local water scarcity index (WSI) of each plant, and

- the indirect WSFP which has been calculated using data collected by thinkstep on the freshwater consumption of the different ancillary materials, of the fuel and of the electricity needed for the production of alumina and aluminium and the relevant water scarcity indexes.
\end{abstract}

Methods The calculation of the direct WSFP follows the requirement of ISO 14046 to aggregate data of sites at locations

Responsible editor: Martin Baitz

Electronic supplementary material The online version of this article (doi:10.1007/s11367-015-0997-1) contains supplementary material, which is available to authorized users.

Kurt Buxmann

kurt.buxmann@gmail.com

1 Route de Sion 28, 3960 Sierre, Switzerland

2 thinkstep AG, Office Switzerland, Technoparkstrasse 2, 8406 Winterthur, Switzerland

3 thinkstep AG, Hauptstraße 111-113, 70771 Leinfelden-Echterdingen, Germany with different water scarcity after multiplication with the local water scarcity index.

For the indirect WSFP, regional averages of the water consumption and water scarcity index were used for an initial screening study to determine fields for further investigation. Results of this study demonstrate that data on evaporation of water from reservoirs of hydropower plants has an extremely high contribution to the indirect WSFP of primary aluminium (79\% of the GLO value and $92 \%$ of the RoW value).

Therefore, a plant-by-plant approach was applied for hydropower which considers the net freshwater consumption of the hydropower reservoirs and uses the local water scarcity index of each power station, individually, for the calculation of the generic WSFP of the country or region. A special treatment has been given to some multipurpose reservoirs which typically have a beneficial effect on water scarcity, i.e. they have a negative WSFP if seasonal water scarcity indices are used.

Results and discussion With this approach, the WSFP of primary aluminium has been calculated as follows:

- $18.2 \mathrm{~m}^{3} \mathrm{H}_{2} \mathrm{Oe} . /$ tonne for global primary aluminium (GLO);

- $9.6 \mathrm{~m}^{3} \mathrm{H}_{2} \mathrm{Oe} /$ tonne for global primary aluminium, excluding China (RoW).

Conclusions In order to avoid distorted results of water footprint studies, in depth analysis of identified hotspots in water consumption is necessary, in this case the plant-by plant approach, in accordance with ISO 14046. Data providers are encouraged to facilitate such analysis by improving the accessibility of such detailed data.

Keywords Evaporation · Hydropower · Primary aluminium • Reservoir $\cdot$ Water footprint $\cdot$ Water scarcity index 


\section{Introduction}

Historically, water scarcity has not been considered as an impact category in LCA studies. Data on water inputs and water outputs were collected on the inventory level, but they were not subject of impact assessment. Since then, water assessments including impact assessment in a LCA context gained much more attention (see Bayart et al. 2010), and there is a large activity in this field including many case studies (see Tillotson et al. 2014 for examples). A recent highlight in these developments was the publication of an ISO standard specifically dedicated to water footprint assessment (ISO 14046).

An important starting point in water footprint assessments on the inventory level is freshwater consumption, also termed consumptive freshwater use, which is defined as "use of freshwater when release into the original drainage basin does not occur because of evapotranspiration, product integration or discharge into different drainage basins or the sea" (Bayart et al. 2010). Freshwater consumption is quantified in volume units, typically litres or cubic metres.

Based on generic water consumption data, life cycle inventory assessments have been performed, e.g. for cars (Bras et al. 2012) which demonstrate that there is significant variability in such generic data depending on the data source. For primary aluminium, calculation of both the water consumption (inventory) and water footprint (impact) is highly sensitive to the treatment of the electricity supply of the aluminium smelters, typically $14 \mathrm{kWh}$ per $\mathrm{kg}$ of primary aluminium, which is mainly produced by hydropower plants. Data about freshwater consumption of power plants is available in the published literature. As an example, the average water consumption by evaporation of 35 selected hydropower plants has been determined as $86 \mathrm{~m}^{3} / \mathrm{GJ}$ or $24 \mathrm{~L} / \mathrm{kWh}$ (Mekonnen and Hoekstra 2012). Other practitioners (Wilson et al. 2012) published data about the freshwater consumption of the different types of power plants in North America, showing that hydropower is the most important freshwater consumer.

Recently published studies on water consumption of hydropower plants have been criticised (Bakken et al. 2013), as not reflecting "true" water consumption from hydropower plants and the beneficial effects of many reservoirs.

The dominant calculation method, i.e. gross evaporation from the reservoir divided by the annual power production, appears to be a too simplistic calculation method that possibly produces a biased picture of the water consumption of hydropower plants, by not considering the water lost by evaporation and transpiration before reservoir impoundment. Furthermore, it is argued that reservoirs are not always part of the problem; on the contrary, they often contribute to the solution of the problems of water scarcity.

The publication of ISO 14046 in 2014 has delivered a definition of the impact category "water scarcity". The local water scarcity index divided by the global average water scarcity index can be used as a characterisation factor to calculate the indicator result of the impact category "water scarcity" which is named "water scarcity footprint (WSFP)".

In a frequently used approach (Pfister et al. 2009), the local water scarcity index (WSI) is based on the ratio of water withdrawal to water availability, but considers also the seasonality in the relevant region, e.g. monsoon. The WSI lies between 0.01 (wet area) and 1 (dry area) which allows the distinction between dry areas and areas with abundant water on a fair basis.

\section{Objective of the study and description of the method}

\subsection{General}

This paper outlines a study to determine the WSFP of primary aluminium, globally, based on a cradle-to-gate system, as illustrated in Fig. 1. The system encompasses all production processes from bauxite mining to ingot production, including their fuel consumption, the production of ancillary materials and the generation of electricity consumed as well as all transportation of intermediate products and ancillaries.

The study intends to be in compliance with the guidance given in ISO 14046 to calculate the WSFP for single processes, sites, systems of sites and systems of processes, including product systems.

Life cycle inventory data, including data on water consumption, has been collected by the International Aluminium Institute (IAI) for the year 2010 from aluminium plants worldwide. In addition to the WSFP, other mid-point indicator results have been determined for the same system, based on these data, namely depletion of fossil energy resources, global warming potential, acidification potential, eutrophication potential, ozone depletion potential and photo-oxidant creation potential (IAI 2014).

The seven indicator results can be considered as a life cycle impact assessment (LCIA) profile of global primary

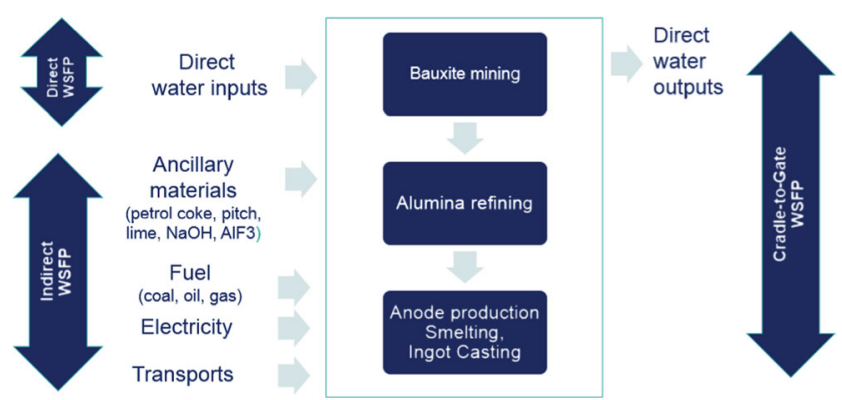

Fig. 1 Direct, indirect and cradle-to-gate water scarcity footprint of primary aluminium ingots 
aluminium, in alignment with published guidance for conducting LCAs for metals and metal products (PE International 2014). This means that the study which is reported here is part of a more comprehensive study to determine the environmental impacts of global primary aluminium, cradleto-gate. Therefore, no additional effort has been made to determine or to evaluate data on water degradation.

The parameters of the LCIA profile have been calculated for global aluminium production including China (GLO) and for the rest of the world excluding China (RoW). This is to take into account the fact that Chinese primary aluminium is less integrated into the global market.

\subsection{Procedure on how to determine the freshwater consumption of aluminium plants}

In order to calculate the water scarcity footprint of a plant, its freshwater consumption has to be determined.

A plant typically measures its annual freshwater input by summing the water which is supplied by external suppliers via water pipes, from site-owned groundwater sources or from rivers or lakes.

The water output in sewage pipes typically consists of polluted wastewater, process water including cooling water and rain water. Rain water input can be calculated as the local annual precipitation per $\mathrm{m}^{2}$ multiplied by the area of the plant (in $\mathrm{m}^{2}$ ). However, only a part of the rain water input leaves the plant through sewage pipes, another significant proportion evaporates within the area of the plant.

According to ISO 14046, only the additional water evaporation of the plant area which is caused by human intervention, i.e. the construction of the plant, contributes to freshwater consumption. For the purpose of this study, it is assumed that evaporation from the plant area does not differ from the evaporation from this area before the plant has been built and therefore this evaporation is not taken into account.

According to ISO 14046, freshwater consumption of aluminium plants includes the following:

- evaporation of water by cooling processes (all plants have such processes except bauxite mines)

- direct discharge of water into the sea (only applicable to plants directly located at the seashore)

- inclusion of water in bauxite which is shipped to customers (only applicable to bauxite mines)

- inclusion of water in bauxite residue followed by evaporation at the disposal area (only applicable to alumina refineries)

Consequently, the freshwater consumption of a plant can be calculated as follows:
$C_{n}=I_{n}-\left(D_{n}-D_{r, n}\right)+D_{p, n}+D_{s, n}$

where

$C_{n} \quad$ is the annual freshwater consumption of this plant

$I_{n} \quad$ is the annual water input to the plant

$D_{n} \quad$ is the annual water discharge from the plant

$D_{r, n}$ is the annual rainwater discharge as part of the water discharge

$D_{p, n}$ is the water included in the product which is annually supplied (only for bauxite mines)

$D_{s, n}$ is the water directly discharged into the sea

All data are measured in cubic metres $\left(\mathrm{m}^{3}\right)$.

The rainwater discharge as part of the water discharge is calculated as follows:

$D_{r, n}=A_{n} \times\left(P_{n}-E_{n}\right)$

where

$A_{n} \quad$ is the area of this plant in $\mathrm{m}^{2}$

$P_{n} \quad$ is the precipitation within the reporting year per $\mathrm{m}^{2}$

$E_{n}$ is the annual water evaporation rate at the location of the plant within the reporting year per $\mathrm{m}^{2}$

In the IAI's LCI survey for 2010 data, separate figures were reported for "water outputs from cooling use" and "water outputs from other uses", with the exception of bauxite mines. For the calculation of the water scarcity footprint, emissions to water are not considered, as they are dealt with in other impact categories. Therefore, both water outputs were added together to obtain the water output $D_{n}$.

\subsection{How to determine the direct WSFP of primary aluminium}

ISO 14046, subclause 5.3.2, states that:

Water inputs or water outputs of different resource types, different quality, different form, different location with different environmental condition indicators or different timing shall not be aggregated in the inventory phase. Aggregation may be performed at the impact assessment phase.

As averaging includes aggregation, "conventional" averaging of freshwater consumption on the inventory level, as used for other LCI data, is not permitted for the determination of the water footprint, if the relevant sites are located in areas with different water scarcities. Therefore, for the purpose of this study, global averages of the water consumption of the aluminium plants have not been calculated.

The annual water scarcity footprint of a plant $n$ is calculated as follows: 
$W F_{\mathrm{Sc}, n}=C_{n} \times \frac{C F_{\mathrm{Sc}, n}}{C F_{\mathrm{Sc}, \mathrm{Glo}}}$

where

$W F_{\mathrm{Sc}, n}$ is the water scarcity footprint of the plant $n$, measured in $\mathrm{L} \mathrm{H}_{2} \mathrm{Oe}$ (litres water equivalents) or $\mathrm{m}^{3} \mathrm{H}_{2} \mathrm{Oe}$.

$C_{n} \quad$ is the annual freshwater consumption of this plant, i.e. the quantity of water which has evaporated, integrated into sold products or waste or directly released into the sea.

$C F_{\mathrm{Sc}, n} \quad$ is the water scarcity index of the location where the plant operates.

$C F_{\text {Sc,Glo }}$ is the average global water scarcity index, i.e. 0.6.

For each site, the water scarcity index is determined via a software based on Google Earth, which is based on Pfister et al. (2009) and can be downloaded through the link http:// www.ifu.ethz.ch/ESD/downloads/EI99plus followed by clicking the option "Freshwater consumption impact factors" (kmz-file).

The direct WSFP per tonne of all reporting bauxite mines is determined by the following:

$W F_{\mathrm{Sc}, \text { Bauxite }}=\frac{\sum W F_{\mathrm{Sc}, \text { Bauxite }, n}}{\sum P_{\text {Bauxite } \mathrm{n}}}$

where

$\sum W F_{\mathrm{Sc}, \mathrm{Bauxite}, n}$ is the sum of all WSFPs of the bauxite mines considered

$\sum P_{\text {Bauxite }, n} \quad$ is the total bauxite production of the reporting bauxite mines, in tonnes

The average direct WSFP of the reporting alumina plants per tonne of alumina, i.e. $W F_{\mathrm{SC} \text {,Alumina, }}$ and of the reporting aluminium smelters per tonne of primary aluminium ingots, i.e. $W F_{\mathrm{SC}, S m e l t e r s}$, is determined in the same way. The smelter includes the processes electrolysis, anode production and ingot casting.

Using one tonne of primary aluminium ingot as the reference flow, the direct WSFP is calculated as follows:

$$
\begin{aligned}
W F_{\mathrm{Sc}, \mathrm{Al}}= & A \times W F_{\mathrm{Sc}, \text { Bauxite }}+B \times W F_{\mathrm{Sc}, \text { Alumina }} \\
& +W F_{\mathrm{Sc}, \text { Smelters }}
\end{aligned}
$$

where

$W F_{\mathrm{Sc}, \mathrm{Al}}$

A

$W F_{\mathrm{Sc}, \text { Bauxite }}$ is the direct WSFP per tonne of primary aluminium is the mass of bauxite required for the production of one tonne of primary aluminium ingot
$W F_{\text {Sc,Alumina }}$

$W F_{\mathrm{Sc}, \text { Smelters }}$

is the direct WSFP per tonne of bauxite, obtained according to Eq. (4)

is the mass of alumina required for the production of one tonne of primary aluminium ingot

is the direct WSFP per tonne of alumina is the direct WSFP per tonne of primary aluminium ingot of the smelters (electrolysis, anode production and casting

\subsection{Preliminary screening assessment to determine the indirect WSFP of primary aluminium}

Ideally, the indirect WSFP of primary aluminium should have been determined for each material and energy flow, as shown in Fig. 1, in the same way as for the direct flows, i.e. by use of the plant-by-plant approach according to ISO 14046.

However, the practical implication of this ISO requirement is hard to meet for data providers, as many aggregated material and energy flows consist of thousands of subprocesses, and the specific location (beyond country level) for each processes has to be known. Therefore, in order to find out to which extent and for which processes further investigation is required, it was decided to conduct a screening assessment (Approach 0) based on the available aggregated average data on national level from the database of the data provider to determine the indirect WSFP of primary aluminium.

The contributions of transport, ancillary materials and fuels production to the indirect WSFP of one tonne of primary aluminium is shown in Table 1. The total contribution of these flows is $1.9 \mathrm{~m}^{3} \mathrm{H}_{2} \mathrm{Oe}$ per tonne (51\% from fuel, $40 \%$ from ancillaries and $9 \%$ from transports).

The contribution of smelter-consumed electricity generation to the indirect WSFP of primary aluminium is based on global energy consumption, power mix and aluminium production data collected and published by the IAI (International Aluminium Institute 2013). The smelters were grouped regionally, i.e. Africa, Asia excl. China, GCC (Arabian Gulf), China, North America, South America, Europe and Oceania, in accordance with the IAI's statistical groupings. This allows calculation of the contribution of each region to the global total or for a single tonne of primary aluminium.

The data provider determined the WSFP parameters for each global region and for each energy source, based on the average water consumption of the power plants of the different energy sources in the relevant region and the average water scarcity index of that region. The WSFP value for gas-fired power plants in the GCC area was assumed to be zero, because the power plants in this area are only using desalinated 
Table 1 Contribution of transports, ancillary materials and fuel to the WSFP of one tonne of primary Al

\begin{tabular}{|c|c|c|c|c|c|}
\hline & \multicolumn{2}{|c|}{ Flow per tonne of primary $\mathrm{Al}$} & \multicolumn{2}{|l|}{ Specific WSFP } & \multirow[t]{2}{*}{ WSFP Total ( $\mathrm{L} \mathrm{H}_{2} \mathrm{Oe} / \mathrm{t}$ prim. $\left.\mathrm{Al}\right)$} \\
\hline & Unit & Value & Unit & Value & \\
\hline Average sea transport & tkm & 19,342 & $\mathrm{~L} \mathrm{H}_{2} \mathrm{Oe} / \mathrm{tkm}$ & 0.0071 & 138 \\
\hline Average road transport & tkm & 10 & $\mathrm{~L} \mathrm{H}_{2} \mathrm{Oe} / \mathrm{km}$ & 0.033 & $<1$ \\
\hline Average rail transport & tkm & 143 & $\mathrm{~L} \mathrm{H}_{2} \mathrm{Oe} / \mathrm{km}$ & 0.19 & 27 \\
\hline Caustic soda & $\mathrm{kg}$ & 152 & $\mathrm{~L} \mathrm{H}_{2} \mathrm{Oe} / \mathrm{kg}$ & 2.49 & 378 \\
\hline Calcined lime & $\mathrm{kg}$ & 78 & $\mathrm{~L} \mathrm{H}_{2} \mathrm{Oe} / \mathrm{kg}$ & 0.09 & 7 \\
\hline Petrol coke & $\mathrm{kg}$ & 295 & $\mathrm{~L} \mathrm{H}_{2} \mathrm{Oe} / \mathrm{kg}$ & 0.26 & 78 \\
\hline Pitch & $\mathrm{kg}$ & 74 & $\mathrm{~L} \mathrm{H}_{2} \mathrm{Oe} / \mathrm{kg}$ & 0.48 & 35 \\
\hline Refractory material & $\mathrm{kg}$ & 10 & $\mathrm{~L} \mathrm{H}_{2} \mathrm{Oe} / \mathrm{kg}$ & 20.0 & 208 \\
\hline Steel & $\mathrm{kg}$ & 6 & $\mathrm{~L} \mathrm{H}_{2} \mathrm{Oe} / \mathrm{kg}$ & 4.82 & 30 \\
\hline Cathode carbon & $\mathrm{kg}$ & 1934 & $\mathrm{~L} \mathrm{H}_{2} \mathrm{Oe} / \mathrm{kg}$ & 0.26 & 2 \\
\hline $\mathrm{AlF}_{3}$ & $\mathrm{~kg}$ & 439 & $\mathrm{~L} \mathrm{H}_{2} \mathrm{Oe} / \mathrm{kg}$ & 1.42 & 23 \\
\hline Chlorine & $\mathrm{kg}$ & 6 & $\mathrm{~L} \mathrm{H}_{2} \mathrm{Oe} / \mathrm{kg}$ & 2.49 & $<1$ \\
\hline Heavy oil & $\mathrm{kg}$ & 177 & $\mathrm{~L} \mathrm{H}_{2} \mathrm{Oe} / \mathrm{kg}$ & 2.05 & 362 \\
\hline Diesel oil & $\mathrm{kg}$ & 5 & $\mathrm{~L} \mathrm{H}_{2} \mathrm{Oe} / \mathrm{kg}$ & 3.13 & 15 \\
\hline Gas & $\mathrm{Nm}^{3}$ & 307 & $\mathrm{~L} \mathrm{H}_{2} \mathrm{Oe} / \mathrm{Nm}^{3}$ & 1.66 & 509 \\
\hline Coal & $\mathrm{kg}$ & 144 & $\mathrm{~L} \mathrm{H}_{2} \mathrm{Oe} / \mathrm{kg}$ & 0.48 & 69 \\
\hline \multicolumn{3}{|l|}{ Total $\left(\mathrm{L} \mathrm{H}_{2} \mathrm{Oe} / \mathrm{t}\right.$ prim. $\left.\mathrm{Al}\right)$} & & & 1880 \\
\hline
\end{tabular}

water, and sea water consumption is not included in the water consumption.

Results are shown in Table 2. The third and fourth column of this table show total annual electricity consumption of the reporting smelters from the different energy sources for the year 2012. These data are published by the IAI under http://www.world-aluminium. org/statistics/primary-aluminium-smelting-powerconsumption/\#data. In the third column showing the RoW data, Chinese data are replaced by zeros.

The 5th and 6th column show the electricity contributions per tonne of primary aluminium in $\mathrm{kWh} / \mathrm{t}$, i.e. the average contributions of the different countries making up the regions and electricity sources to the production of one tonne of generic primary aluminium. The sum of all these figures is $15,392 \mathrm{kWh} /$ tonne which is the global average electricity consumption of smelters, including electrolysis, anode production and ingot casting, for the production of one tonne of primary aluminium, based on the data of 2010 (International Aluminium Institute 2013). The 7th column shows the WSFP parameters of the different forms of electricity, measured in litres water equivalents/kWh $\left(\mathrm{L} \mathrm{H}_{2} \mathrm{Oe} /\right.$ $\mathrm{kWh}$ ), as determined by the data provider, by multiplying the average water consumption per $\mathrm{kWh}$ by the average WSI of the region, according to Approach 0 . From this, the WSFP parameters for the different contributions of electricity for the production of one tonne of primary aluminium are calculated.
A summary of the results of the preliminary screening assessment is given in Table 3. In addition to the smelter electricity, Table 3 includes the electricity consumption at the bauxite mines and the alumina refineries as "other electricity".

According to this preliminary screening assessment using Approach 0 , the contribution of the electricity from hydropower to the total of the indirect WSFP is very high, i.e. $79 \%$ for GLO and $92 \%$ for RoW.

\subsection{Choice of the procedure to determine the indirect WSFP of primary aluminium}

According to Approach 0, the WSFP of hydropower is based on the average water evaporation of reservoirs and the average water scarcity index (WSI) values of the relevant region, e.g. 0.50 for North America. However, such reservoirs, if they are built for the generation of hydroelectricity, are typically located in areas with abundant water, i.e. with WSI values much lower than the national average of the country.

Therefore, it was decided to apply, as a first step, the plantby-plant approach for the calculation of the WSFP of the electricity from hydropower. In order to be compliant with ISO 14046, the WSFP values for the other material and energy flows, as shown in Tables 1 and 2, should have been calculated by use of the plant-by-plant approach, as well. However, due to the complexity of such an investigation (according to EEA 2015 more than 3500 combustion plants with a rated thermal input equal to or greater than $50 \mathrm{MW}$ exist in the EU28 alone) compared to a lower contribution of these 
Table 2 Contribution of electricity generation for smelters to the indirect WSFP of primary Al

\begin{tabular}{|c|c|c|c|c|c|c|c|c|}
\hline \multirow[t]{2}{*}{ Region } & \multirow[t]{2}{*}{ Source of electricity } & \multicolumn{2}{|c|}{$\begin{array}{l}\text { Electricity consumption total } \\
\text { (GWh) }\end{array}$} & \multicolumn{2}{|c|}{$\begin{array}{l}\text { Electricity contribution per tonne } \\
(\mathrm{kWh} / \mathrm{t})\end{array}$} & \multirow[t]{2}{*}{ WSFP $\left(\mathrm{L} \mathrm{H}_{2} \mathrm{Oe} / \mathrm{kWh}\right)$} & \multicolumn{2}{|c|}{$\begin{array}{l}\text { WSFP }\left(\mathrm{L} \mathrm{H}_{2} \mathrm{Oe} /\right. \\
\mathrm{t})\end{array}$} \\
\hline & & GLO & RoW & GLO & RoW & & GLO & RoW \\
\hline \multirow[t]{2}{*}{ Africa } & Hydro & 9376 & 9376 & 240 & 450 & 12.23 & 2935 & 5503 \\
\hline & Coal & 10,193 & 10,193 & 261 & 489 & 0.80 & 208 & 390 \\
\hline \multirow[t]{2}{*}{ Asia excl. China } & Hydro & 782 & 782 & 20 & 38 & 3.60 & 72 & 135 \\
\hline & Coal & 8365 & 8365 & 214 & 402 & 1.32 & 283 & 530 \\
\hline $\mathrm{GCC}$ & Gas & 37,073 & 37,073 & 949 & 1780 & 0.00 & 0 & 0 \\
\hline \multirow[t]{2}{*}{ China } & Hydro & 28,058 & 0 & 718 & 0 & 18.18 & 13,060 & 0 \\
\hline & Coal & 252,525 & 0 & 6466 & 0 & 1.55 & 10,051 & 0 \\
\hline \multirow[t]{2}{*}{ South America } & Hydro & 27,117 & 27,117 & 694 & 1302 & 14.02 & 9733 & 18,251 \\
\hline & Gas & 4689 & 4689 & 120 & 225 & 1.40 & 168 & 315 \\
\hline \multirow[t]{4}{*}{ North America } & Hydro & 51,832 & 51,832 & 1327 & 2489 & 18.80 & 24,950 & 46,785 \\
\hline & Coal & 15,128 & 15,128 & 387 & 726 & 1.26 & 489 & 917 \\
\hline & Gas & 340 & 340 & 9 & 16 & 1.37 & 12 & 22 \\
\hline & Nuclear & 404 & 404 & 10 & 19 & 2.05 & 21 & 40 \\
\hline \multirow[t]{5}{*}{ Europe } & Hydro & 100,737 & 100,737 & 2579 & 4837 & 0.39 & 1018 & 1908 \\
\hline & Coal & 8954 & 8954 & 229 & 430 & 0.77 & 176 & 331 \\
\hline & Oil & 322 & 322 & 8 & 15 & 0.80 & 7 & 12 \\
\hline & Gas & 4174 & 4174 & 107 & 200 & 0.45 & 48 & 90 \\
\hline & Nuclear & 9566 & 9566 & 245 & 459 & 1.83 & 449 & 842 \\
\hline \multirow[t]{2}{*}{ Oceania } & Hydro & 7722 & 7722 & 198 & 371 & 20.32 & 4017 & 7533 \\
\hline & Coal & 23,823 & 23,823 & 610 & 1144 & 0.94 & 572 & 1073 \\
\hline Total & & 601,184 & 320,601 & 15,392 & 15,392 & & 68,268 & 84,677 \\
\hline
\end{tabular}

processes to water consumption, such a more detailed approach has to be left for future studies.

The plant-by-plant approach to determine the generic WSFP per $\mathrm{kWh}$ hydropower in specific countries or regions was applied in the same way as for the determination of the direct WSFP of the aluminium plants:
1. Specify the country/region for which the generic WSFP value of hydropower plants for primary aluminium should be determined;

2. Collect specific net freshwater consumption data of selected hydropower plants in this country/ region;
Table 3 Results of the preliminary screening assessment to determine the indirect water footprint of primary aluminium

\begin{tabular}{|c|c|c|c|c|}
\hline & \multicolumn{2}{|c|}{ WSFP ( $\left.\mathrm{L} \mathrm{H}_{2} \mathrm{Oe} . / \mathrm{t}\right)$} & \multicolumn{2}{|c|}{ Percent of total indirect WSFP } \\
\hline & GLO & RoW & $\operatorname{GLO}(\%)$ & RoW (\%) \\
\hline Electricity from hydropower & 56 & 80 & 79 & 92 \\
\hline Electricity from coal & 12 & 3 & 17 & 4 \\
\hline Electricity from gas & $<1$ & $<1$ & $<1$ & $<1$ \\
\hline Electricity from nuclear plants & $<1$ & $<1$ & $<1$ & 1 \\
\hline Smelter electricity, total & 68 & 85 & 97 & 98 \\
\hline Other electricity & $<1$ & $<1$ & $<1$ & $<1$ \\
\hline Fuel & $<1$ & $<1$ & 1 & 1 \\
\hline Ancillary material & $<1$ & $<1$ & 1 & $<1$ \\
\hline Transports & $<1$ & $<1$ & $<1$ & $<1$ \\
\hline Total & 71 & 87 & 100 & 100 \\
\hline
\end{tabular}


3. Determine the WSFP for each of the hydropower plants in the selected country/region by multiplying its net freshwater consumption by its local water scarcity index;

4. Add up the WSFP values for the different hydropower plants to obtain a total WSFP;

5. Divide the total WSFP by the total annual electricity production of these sites.

A special effort has been made to make sure that the net water consumption has been determined for each hydropower plant, after deduction of the evaporation of the surface of the reservoir before the reservoir has been built.

Specific countries or regions with a significant use of hydropower for aluminium production were selected: Brazil, Venezuela, USA (NW and NE), Canada (Quebec), China, Iceland, Norway, Sweden, Siberia, Australia, Egypt, Ghana, Cameroon and Mozambique.

For each country/region, a number of large hydropower reservoirs have been selected in order to obtain representative results.

The hydropower study was undertaken by the same data provider as the preliminary screening assessment. Some of the hydropower reservoirs which were considered in the study were located in dry areas and were multifunctional, i.e. they contributed, in addition to the generation of electricity, to the water supply of households and irrigation and in some cases to flood control. For such reservoirs, two different approaches were explored:

- Approach I: no consideration of multifunctionality, i.e. allocation of the whole water consumption to the generation of electricity;

- Approach II: consideration of multifunctionality.

\section{Results}

\subsection{The direct WSFP of primary aluminium}

The direct WSFP parameters of primary aluminium for GLO and RoW are shown in Table 4. Within the LCI

Table 4 Direct WSFP of aluminium plants, based on the data of the LCI 2010 survey of the IAI, in $\mathrm{m}^{3} \mathrm{H} 2 \mathrm{Oe} /$ tonne of primary aluminium

\begin{tabular}{lll}
\hline & GLO & RoW \\
\hline Bauxite mines & 0.23 & 0.23 \\
Alumina refineries & 1.87 & 0.84 \\
Smelters, incl. anode plants and cast-houses & 0.043 & 0.043 \\
Total & 2.14 & 1.12 \\
\hline
\end{tabular}

2010 survey of the IAI, no data from Chinese plants was reported. The WSFP data for China has been determined by assuming the same freshwater consumption of alumina refineries as RoW refiners, but taking into account the higher water stress indices of the Chinese refineries.

The main contribution to WSFP is from refineries, where a significant part of the water is used for bauxite digestion and in its final form becomes part of bauxite residue and eventually evaporates after disposal.

\subsection{The WSFP of hydropower plants according to Approach I}

Table 5 shows the results for the different countries which have been considered. It can be seen that in most of the countries, the WSFP is below $0.5 \mathrm{~m}^{3} \mathrm{H}_{2} \mathrm{Oe} / \mathrm{MWh}$, with the exception of China, Australia and Egypt where reservoirs include multifunctional ones.

The detailed analysis of the selected hydropower plants in Canada/Quebec is given in the Electronic Supplementary Material.

\subsection{The WSFP of hydropower plants according to Approach II}

The three Australian reservoirs (Tumut 3 and Murray 1 and 2) which contributed to a high WSFP in Table 5 were identified as multifunctional reservoirs belonging to the Snowy Mountains scheme which also serves for irrigation. The Egyptian Aswan reservoir has also been built mainly for irrigation and flood control. Before this dam was built, the Nile river basin was flooded every year between June and October for a length of $1000 \mathrm{~km}$ causing significant evaporation. As for China, 1 from 10 reservoirs has been identified to be clearly multifunctional.

If a reservoir also serves for irrigation and domestic water supply, it typically collects water in the rainy season and releases water in the dry season, in quantities which are often two orders of magnitude higher than the evaporation losses. If the WSFP of such a reservoir is calculated by use of monthly WSI parameters (Pfister and Bayer 2014), i.e. a WSI close to one in the dry season and a lower WSI in the wet season, then typically a negative WSFP results, demonstrating the positive effect of the reservoir related to water scarcity. Therefore, in such cases, it is not appropriate to assign a positive WSFP value to the generation of hydropower. Consequently, for the Approach II, the WSFP values have been changed to zero for multifunctional reservoirs. 
Table 5 WSFP values for the hydropower fractions in the different national grids of countries or regions where significant quantities of primary aluminium are produced from hydropower (Approach I)

\begin{tabular}{|c|c|c|c|}
\hline Country/region & $\begin{array}{l}\text { Annual electricity production } \\
\text { of analysed reservoirs Mio MWh }\end{array}$ & WSFP $\left(\mathrm{m}^{3} \mathrm{H}_{2} \mathrm{Oe} / \mathrm{MWh}\right)$ & $\begin{array}{l}\text { Representativity (based on } \\
\text { hydropower production) (\%) }\end{array}$ \\
\hline Ghana & 5.7 & 0.26 & 83 \\
\hline Cameroon & 1.90 & 0.07 & 48 \\
\hline Mozambique & 15.8 & 0.36 & 94 \\
\hline Egypt & 7.4 & 89 & 58 \\
\hline China & 145 & 2.3 & 26 \\
\hline Canada-Quebec $^{2}$ & 57 & 0.063 & 16 \\
\hline USA-NE/NW & 70 & 0.75 & 26 \\
\hline Brazil & 96 & 0.35 & 25 \\
\hline Venezuela & 64 & 0.24 & 25 \\
\hline Norway & 16.2 & 0.0078 & 26 \\
\hline Sweden & 3.6 & 0.065 & 5.6 \\
\hline Iceland & 7.5 & 0.0048 & 62 \\
\hline Russia/Siberia & 78 & 0.129 & 48 \\
\hline Australia & 3.0 & 15.5 & 21 \\
\hline
\end{tabular}

${ }^{a}$ See also Electronic Supplementary Material

The new values are shown in Table 6.

\subsection{WSFP of primary aluminium based on the different approaches}

Using the data submitted by the data provider, the WSFP values of primary aluminium, cradle-to-gate, are shown in Table 7 according to Approach I and Approach II.

It can be seen that the electricity supply, especially hydropower, still constitutes around $80 \%$ of the total impact. Table 7 also shows that the WSFP values are significantly lower when using Approach II. For RoW, the total WSFP is $9.6 \mathrm{~m} 3 \mathrm{H} 2 \mathrm{Oe}$ per tonne of primary $\mathrm{Al}$ instead of $25 \mathrm{~m}^{3} \mathrm{H} 2 \mathrm{Oe}$ per tonne of primary $\mathrm{Al}$ and the contribution of the hydropower supply is only $20 \%$ instead of $70 \%$.
Table 8 and Fig. 2 give an overview of WSFP results based on the different approaches (GLO, RoW, Approach 0, Approach I, Approach II) and the contribution of the direct WSFP of hydropower and the other indirect WSFPs.

As discussed in 4.2, 4.3 and 4.4, Approach II can be considered as the preferred option. Table 9 and Fig. 2 show the results only for this option.

Assuming that Approach II is the most reasonable one, Table 9 shows the final results for GLO and RoW. The highest contribution to the indirect WSFP is from the electricity supply to the smelters.

The quality of the GLO data, especially the representativeness, could be improved in the future with more direct water consumption data from Chinese plants.

Table 6 WSFP values for the hydropower fractions in the different national grids of countries where multifunctional reservoirs are located (Approach I and Approach II)

\begin{tabular}{|c|c|c|c|c|}
\hline \multirow[t]{2}{*}{ Country/region } & \multirow[t]{2}{*}{ Annual electricity production (Mio MWh) } & \multicolumn{2}{|c|}{ WSFP $\left(\mathrm{m}^{3} \mathrm{H}_{2} \mathrm{Oe} / \mathrm{MWh}\right)$} & \multirow[t]{2}{*}{ Representativity } \\
\hline & & Approach I & Approach II & \\
\hline Egypt & 7.4 & 89 & 0 & $58 \%$ \\
\hline Africa ( 4 countries $)^{a}$ & 31 & 22 & 0.052 & $76 \%$ \\
\hline China & 145 & 2.3 & 0.68 & $26 \%$ \\
\hline Australia & 3.0 & 15.4 & 0 & $21 \%$ \\
\hline
\end{tabular}

${ }^{\mathrm{a}}$ Ghana, Cameroon, Mozambique and Egypt 
Table 7 WSFP of primary aluminium, cradle-to-gate, detailed contribution analysis $\left(\mathrm{m}^{3}\right.$ $\mathrm{H}_{2} \mathrm{Oe}$ per tonne of primary $\mathrm{Al}$ )

\begin{tabular}{|c|c|c|c|c|c|c|}
\hline & \multicolumn{2}{|c|}{ WSFP $\left(\mathrm{m}^{3} \mathrm{H}_{2} \mathrm{Oe} / \mathrm{t}\right)$} & \multicolumn{4}{|c|}{ Contribution to total value } \\
\hline & GLO & RoW & GLO-I & GLO-II & RoW-I & RoW-II \\
\hline Direct water use in plants & 2.1 & 1.12 & $8 \%$ & $11 \%$ & $4 \%$ & $12 \%$ \\
\hline Electricity from hydropower-Approach I & 11.0 & 17.6 & $40 \%$ & & $70 \%$ & \\
\hline Electricity from hydropower-Approach II & 1.53 & 2.0 & & $8 \%$ & & $20 \%$ \\
\hline Electricity from coal & 11.9 & 3.4 & $43 \%$ & $66 \%$ & $13 \%$ & $35 \%$ \\
\hline Electricity from oil & 0.01 & 0.01 & $0 \%$ & $0 \%$ & $0 \%$ & $0 \%$ \\
\hline Electricity from gas & 0.23 & 0.43 & $1 \%$ & $1 \%$ & $2 \%$ & $4 \%$ \\
\hline Electricity from nuclear plants & 0.47 & 0.88 & $2 \%$ & $3 \%$ & $3 \%$ & $9 \%$ \\
\hline Electricity, total—Approach I & 24 & 22 & $85 \%$ & & $88 \%$ & \\
\hline Electricity, total—Approach II & 14.2 & 6.6 & & $78 \%$ & & $69 \%$ \\
\hline Fuel & 0.95 & 0.95 & $3 \%$ & $5 \%$ & $4 \%$ & $10 \%$ \\
\hline Ancillary material & 0.76 & 0.76 & $3 \%$ & $4 \%$ & $3 \%$ & $8 \%$ \\
\hline Transports & 0.17 & 0.17 & $1 \%$ & $1 \%$ & $1 \%$ & $2 \%$ \\
\hline Total-Approach I & 28 & 25 & $100 \%$ & & $100 \%$ & \\
\hline Total-Approach II & 18.2 & 9.6 & & $100 \%$ & & $100 \%$ \\
\hline
\end{tabular}

\begin{tabular}{lllllll}
\hline & GLO-0 & RoW-0 & GLO-I & RoW-I & GLO-II & RoW-II \\
\hline Direct water use in plants & 2.14 & 1.12 & 2.1 & 1.12 & 2.1 & 1.12 \\
Electricity from hydropower & 56 & 80 & 11.0 & 17.6 & 1.53 & 1.95 \\
Other indirect WSFP & 14.5 & 6.6 & 14.5 & 6.6 & 14.5 & 6.6 \\
Total & 73 & 88 & 28 & 25 & 18.2 & 9.6 \\
\hline
\end{tabular}

Table 8 WSFP of primary aluminium, cradle-to-gate, simplified contribution analysis $\left(\mathrm{m}^{3} \mathrm{H}_{2} \mathrm{Oe}\right.$ per tonne of primary $\mathrm{Al})$

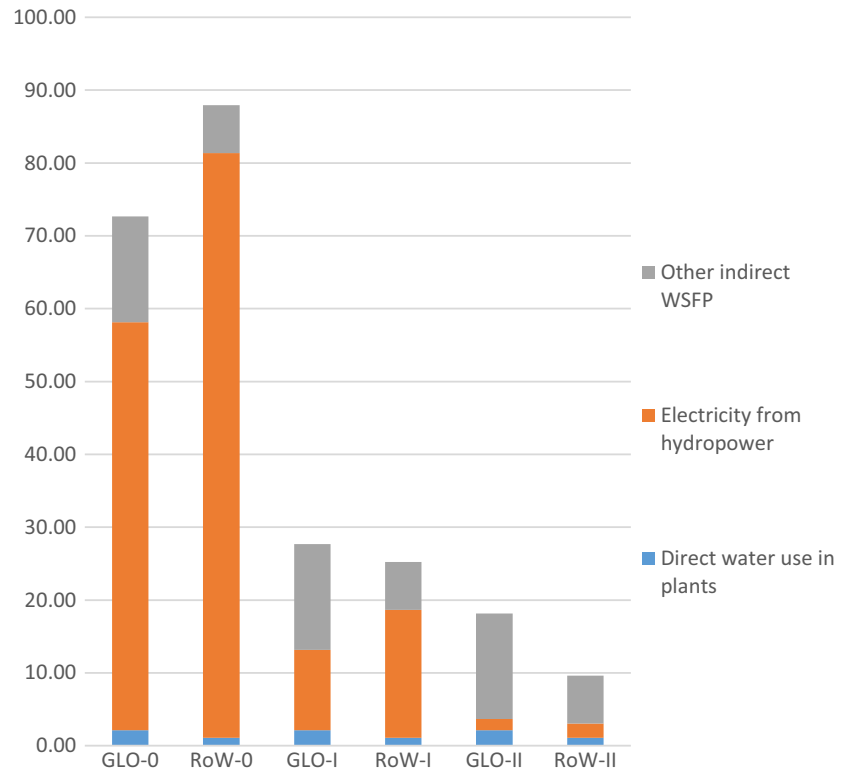

Fig. 2 WSFP of primary aluminium, cradle-to-gate, simplified contribution analysis $\left(\mathrm{m}^{3} \mathrm{H} 2 \mathrm{Oe}\right.$. per tonne of primary $\left.\mathrm{Al}\right)$
Table 9 WSFP of primary aluminium, cradle-to-gate, simplified contribution analysis, Approach $\mathrm{II}\left(\mathrm{m}^{3} \mathrm{H}_{2} \mathrm{Oe}\right.$ per tonne of primary $\left.\mathrm{Al}\right)$

\begin{tabular}{lcl}
\hline & GLO & RoW \\
\hline Direct water use in plants & 2.1 & 1.12 \\
Electricity supply of smelters & 14.2 & 6.6 \\
Other indirect WSFP & 1.88 & 1.88 \\
Total & 18.2 & 9.6 \\
\hline
\end{tabular}




\section{Discussion}

As demonstrated, it is very important to apply the plant-byplant approach to calculate the WSFP of primary aluminium and for electricity in general. However, for the calculation of the indirect WSFP of primary aluminium, the necessary data are not readily available, and a significant effort was necessary to apply this approach for the hydropower generated supply of electricity to aluminium smelters.

However, the WSFP parameters related to electricity supply still are high. As shown in Table 7, in Approach II, the contribution of smelter electricity is $78 \%$ for GLO and $69 \%$ for RoW. This is caused by a high contribution of the WSFP of the electricity production from coal (66\% for GLO and $35 \%$ for RoW). Obviously, the plant-by-plant approach has not been used for the calculation of the WSFP of coal energy. The next step is to refine the results of this study by applying the plantby-plant approach to coal-fired power plants, as well.

As for the electricity from gas-fired power plants, it has been taken into account that $90 \%$ of this electricity is generated in the Arabian Gulf area where these plants use desalinated water. As only freshwater consumption contributes to the WSFP, the freshwater consumption of these power plants has been assumed to be zero. Validation of this assumption could be achieved with further studies on the individual gasfired power plants in the Gulf area.

The WSFP values of the hydroelectric plants in the different countries/regions also need further refinement and, in particular, the calculation of the net water consumption and the inclusion of additional reservoirs in order to increase the representativeness. A special effort is needed to determine the multifunctional reservoirs and to calculate the real WSFP by use of seasonal WSI values.

The WSI values used for this study are calculated for each site according to the ratio water withdrawal vs water availability and further considerations. In the literature, alternative approaches to calculate WSI values are also presented (Boulay et al. 2011; Hanasaki et al. 2008). The adoption of an alternative approach, e.g. WSI values based on the ratio of freshwater consumption vs water availability, would result in different WSFP parameters for primary aluminium.

This study calculated the direct WSFP of primary aluminium, based on global aluminium data as collected by the IAI for the year 2010. The best available data was used, but there is potential to further improve data quality. A revision of the direct WSFP data will take place based on a new LCI survey for the year 2015 .

Knowing all these uncertainties, a quantification of the data quality has not been undertaken, as the main objective of this paper was to demonstrate a consistent model in accordance with ISO 14046. Future surveys based on the findings of this study will allow a more robust assessment of uncertainties.

\section{Conclusions}

It has been shown in this report that it can be very important to calculate WSFP parameters by using the "plant-by-plant approach" based on ISO 14046 where the aggregation of site specific data is only allowed after impact assessment. Therefore, default water assessment values based on averages which are used in LCA databases should be used for screening purposes only. Where hotspots are detected and more detailed data is available, in depth analysis will improve the quality of results significantly. Further efforts are necessary to make sure that the requirements of ISO 14046 can be met in practice and to calculate parameters in accordance with this standard. Especially, the data on electricity supply which is a major contributor to the WSFP needs special consideration.

Open Access This article is distributed under the terms of the Creative Commons Attribution 4.0 International License (http:// creativecommons.org/licenses/by/4.0/), which permits unrestricted use, distribution, and reproduction in any medium, provided you give appropriate credit to the original author(s) and the source, provide a link to the Creative Commons license, and indicate if changes were made.

\section{References}

Bakken TH, Killingtveit Å, Engeland K, Alfredsen K, Harby A (2013) Open access water consumption from hydropower plants-review of published estimates and an assessment of the concept. Hydrol Earth Syst Sci 17:3983-4000

Bayart JB, Bulle C, Deschênes L, Margni M, Pfister S, Vince F, Koehler A (2010) A framework for assessing off-stream freshwater use in LCA. Int J Life Cycle Assess 15:439-453

Boulay A-M, Bulle C, Bayart J-B, Deschenes L, Margni M (2011) Regional characterization of freshwater use in LCA: modeling direct impacts on human health. Environ Sci Technol 45(20):8948-8957

Bras B, Tejada F, Yen J, Zullo J, Guldberg T (2012) Quantifying the life cycle water consumption of a passenger vehicle, SAE International

Hanasaki N, Kanae S, Oki T, Masuda K, Motoya K, Shirakawa N, Shen Y, Tanaka K (2008) An integrated model for the assessment of global water resources-Part 1: model description and input meteorological forcing. Hydrol Earth Syst Sci 12:1007-1025

International Aluminium Institute (2013) Global life cycle inventory data for the primary aluminium industry-year 2010 data http://www. world-aluminium.org/media/filer_public/2013/10/17/2010_life cycle_inventory_report.pdf

International Aluminium Institute (2014) Environmental metrics reportyear 2010 data. http://www.world-aluminium.org/media/filer public/2014/10/21/final_environmental_metrics_report.pdf

Mekonnen MM, Hoekstra AY (2012) The blue water footprint of electricity from hydropower. Hydrol Earth Syst Sci 16:179-187 
PE International (2014) Harmonization of LCA methodologies for metals. A whitepaper providing guidance for conducting LCAs for metals and metal products version 1.01. https://www.icmm.com/document/6657

Pfister S, Bayer P (2014) Monthly water stress: spatially and temporally explicit consumptive water footprint of global crop production. J Clean Prod 73:52-62

Pfister S, Koehler A, Hellweg S (2009) Assessing the environmental impacts of freshwater consumption in LCA. Environ Sci Technol 43(11):4098-4104
Tillotson M, Liu J, Guan D, Wu P, Zhao X, Zhang G et al (2014) Water footprint symposium: where next for water footprint and water assessment methodology? Int J Life Cycle Assess 19:1561-1565

Wilson W, Leipzig T, Griffiths-Sattenspiel B (2012) Burning our riversthe water footprint of electricity. A River Network Report, Rivers, Energy \& Climate Program. www.rivernetwork.org 